\title{
IMPORTÂNCIA DAS INFORMAÇÕES DA ESCRITURAÇÃO FISCAL PARA A TOMADA DE DECISÕES DAS FARMÁCIAS DE TANGARÁ DA SERRA - MT.
}

\author{
Drielly Glender Rocha Silva ${ }^{1}$ \\ Marcelo Evandro Alves ${ }^{2}$
}

\section{RESUMO}

Este trabalho tem por objetivo divulgar a importância da Escrituração Fiscal na visão dos empresários do ramo farmacêutico de Tangará da Serra - MT e também analisar se os escritórios de contabilidade de Tangará da Serra - MT informam aos seus clientes quanto à importância da escrituração fiscal no segmento comercial farmacêutico; demonstrar que as informações geradas pelo profissional contábil são necessárias para auxiliar no processo decisório de suas empresas, garantindo assim o sucesso destas. Para alcançar este objetivo foram realizadas duas etapas de pesquisa. Na primeira etapa, realizou-se o levantamento bibliográfico sobre o tema da pesquisa. Na segunda, foi utilizado um levantamento de dados com 25 escritórios de contabilidade onde foi selecionada uma amostra onde apenas os que prestam serviços a farmácias foram entrevistados, e 35 empresas do ramo farmacêutico de Tangará da Serra - MT. Os questionários foram compostos por perguntas fechadas e foram aplicados entre os dias 15 e 30 de julho de 2011. Estes revelam que os escritórios de contabilidade transmitem informações quanto a importância da escrituração fiscal, porém não foi o que afirmaram as empresas do ramo farmacêutico, pois apenas algumas as recebem e as aplicam para a tomada de decisão.

Palavras-chave: Escrituração Fiscal, Informação, Escrituração Fiscal Digital

\section{INTRODUÇÃO}

A competitividade tem se tornado constante no processo de globalização. A qualidade dos produtos e serviços oferecidos, além do atendimento de seus clientes com maior qualidade são fatores que influenciam proporcionalmente à receita da empresa, afetando o posicionamento e o direcionamento administrativo da entidade. Através das informações extraídas das demonstrações contábeis e/ou relatórios gerenciais podem-se mensurar o desempenho da organização e planejar as ações da entidade quanto à produção, investimentos, desenvolvimento tecnológico, estratégias de mercado e outros que provoquem visão de futuro, no intuito de assegurar que o gestor tome as melhores decisões para o futuro de sua organização (RAUPP, 2000). Com esse avanço da tecnologia, a Escrituração Fiscal também vem se modernizando. Até pouco tempo era feita manualmente, na atualidade pode ser feito por um método mecanizado ou digital, agilizando o processo de Escrituração Fiscal. Sendo

${ }^{1}$ Acadêmico do Curso de Ciências Contábeis, da Universidade do Estado de Mato Grosso Campus Universitário de Tangará da Serra - UNEMAT, drikaglender@hotmail.com

${ }^{2}$ Prof. do Departamento de Ciências Contábeis, da Universidade do Estado de Mato Grosso Campus Universitário de Tangará da Serra - UNEMAT, marcelo.evandro@unemat.br 
assim foi proposto o seguinte tema: "Importância das informações da Escrituração Fiscal para a tomada de decisões das farmácias de Tangará da Serra - MT”.

Este trabalho justifica-se pois a Escrituração Fiscal também está se adaptando a essas mudanças, os livros fiscais que antes tomavam tempo e esforços, pelo fato de que eram elaborados manualmente, hoje com o avanço da tecnologia se tornam mais ágeis, as informações chegam ao fisco mais rapidamente e com uma porcentagem mínima de erro, além de dificultar as fraudes, facilitando e deixando mais ágil o trabalho da fiscalização.

O objetivo deste artigo é analisar se os escritórios de contabilidade de Tangará da Serra - MT informam aos seus clientes quanto à importância da escrituração fiscal no segmento comercial farmacêutico. O problema a ser pesquisado é: Os escritórios de contabilidade de Tangará da Serra - MT informam aos seus clientes quanto à importância da escrituração fiscal no segmento comercial farmacêutico? Para instrumento de coleta de dados foi utilizado questionário semi-estruturado.

Através dessas informações foram determinadas as hipóteses:

H1 - Os escritórios de contabilidade de Tangará da Serra - MT informam seus clientes quanto à importância da escrituração fiscal.

H2 - Os clientes recebem e utilizam informação da importância da escrituração fiscal de seus respectivos escritórios de contabilidade.

Além de contribuir com a fiscalização, essas transformações também afetam na cobrança de impostos, pois através dela a fiscalização pode identificar se foi ou não realizado o pagamento dos mesmos.

\section{REFERÊNCIAL TEÓRICO}

\subsection{Profissão Contábil}

De acordo com Fortes (2005, p.23) "a profissão contábil, atualmente regulamentada pelo Decreto-Lei $n^{\circ}$ 9.295/46, prevê duas categorias profissionais: contador e técnico em contabilidade, com algumas prerrogativas comuns e outras privativas somente dos contadores. O Contador é formado em Ciências Contábeis e possuidor do registro no Conselho Regional de Contabilidade. E o Técnico em Contabilidade que possui o certificado de conclusão de segundo grau com habilitação de Técnico em Contabilidade, mas que para exercer a profissão deverá igualmente ao Contador, ser registrado no Conselho Regional de Contabilidade. 
Para o Estado a contabilidade é utilizada como uma forma de fiscalização de regularidade fiscal, pois é através dela que as informações chegam até ele.

\subsubsection{Função e Importância}

A tarefa básica do Contador segundo Iudícibus e Marion (2007, p.43) "é produzir e/ou gerenciar informações úteis aos usuários da contabilidade para a tomada de decisões". Juntamente com Ribeiro (2005, p.04) que diz: “A principal finalidade da contabilidade é fornecer informações de ordem econômica e financeira sobre o patrimônio, para facilitar as tomadas de decisões por parte dos seus usuários". Deixando claro que o profissional contábil tem a função de fornecer informações as quais terão capacidade de orientar as tomadas de decisões, para o melhor controle de forma a evidenciar a situação patrimonial da entidade.

Maroja (2007) enfatiza que o sucesso ou o fracasso de uma empresa depende das orientações de um Profissional Contábil.

Os pequenos e microempresários necessitam desse apoio e o profissional da
contabilidade tem condições de auxiliar no processo de gestão da empresa, de forma
a evitar que os novos negócios reforcem as estatísticas das empresas que fracassam.
O contador tem o conhecimento de uma ferramenta de grande valor para o pequeno
empreendedor, a Contabilidade Gerencial, que oferece informações estratégicas com
o intuito de possibilitar aos gestores a tomada de decisões mais seguras (MAROJA
2007).

Diante disso pode-se estabelecer a relevância dos profissionais contábeis perante a sociedade.

\subsubsection{Qualidade da Informação}

As informações que os profissionais de contabilidade passam aos seus contribuintes são de essencial importância para a tomada de decisões da empresa.

Segundo Iudícibus e Marion (2002, p. 64) "uma das formas de avaliar a qualidade da informação contábil e, portanto, sua utilidade (benefício), quando comparada ao custo, é analisar algumas qualidades ou características que deve possuir, tais como: compreensibilidade, relevância, confiabilidade e comparabilidade”.

\subsection{Compreensibilidade}

A informação precisa ser completa e demonstrar todos os aspectos contábeis referentes às operações, não evidenciando as compensações.

De acordo com o pensamento de Iudícibus (2007, p. 85) a informação "deve ser exposta da forma mais compreensível possível, para que o usuário possa, efetivamente, entendê-la e utilizá-la de forma cabal nas tomadas de decisões". 


\subsection{Relevância}

É uma das características mais importantes das informações, pois uma informação pra ser relevante precisa influenciar nas decisões econômico-financeiras.

Dessa forma Iudícibus e Marion (2002, p.65) afirmam que a informação é relevante "quando ela influencia as decisões econômicas dos usuários ajudando-os a avaliar eventos passados, presentes e futuros ou confirmando ou corrigindo suas avaliações passadas".

\subsection{Confiabilidade}

As informações precisam ser confiáveis, mas para isso precisam ser isentas de erros materiais. Para assim serem aceitas pelos usuários como informações fielmente confiáveis.

Iudícibus (2007, p. 85) diz que para serem confiáveis, as informações contábeis, além de sua integralidade ou completeza, devem ser baseada nos Princípios Fundamentais de Contabilidade (Postulados, Princípios e Convenções) e, em geral, nos preceitos da doutrina contábil.

\subsection{Comparabilidade}

Precisam condicionar aos seus usuários comparações, tanto com outros anos como com outras entidades, proporcionando assim condições de identificar seus desempenhos financeiros, sua situação patrimonial e as mudanças ocorridas.

Conforme Iudícibus e Marion (2002, p.66) "os usuários precisam ter condições de comparar as demonstrações contábeis de uma entidade através de anos afim de identificar tendências e sua situação patrimonial e financeira e em seu desempenho".

\subsection{Escrituração de Livros Fiscais de Registro de Entrada e Saída}

\subsubsection{Conceito}

Através da escrituração a contabilidade levanta e registra os dados fiscais, facilitando assim para que o fisco analise-os. Ela é composta por livros e documentos que devem ser escriturados rigorosamente em dia. Oliveira (2005, apud DUARTE, 2009).

\subsubsection{Livros Fiscais}

Conforme o Art. 217 da Lei $n^{\circ}$ 7.098/98:

Art. 217 Os contribuintes deverão manter, em cada um dos estabelecimentos, os seguintes livros fiscais, de conformidade com as operações e prestações que realizarem:

I - Registro de Entradas, modelo 1;

II - Registro de Entradas, modelo 1-A;

III - Registro de Saídas, modelo 2;

IV - Registro de Saídas, modelo 2-A;

V - Registro de Controle de Produção e de Estoque, modelo 3; 
VI - Registro de Selo Especial de Controle, modelo 4;

VII - Registro de Impressão de Documentos Fiscais, modelo 5;

VIII - Registro de Utilização de Documentos Fiscais Termos de Ocorrências, $\underline{\text { modelo } 6}$

IX - Registro de Inventário modelo 7;

X - Registro de Apuração do IPI, modelo 8;

XI - Registro de Apuração do ICMS, modelo 9;

XII - Livro de Movimentação de Combustíveis -LMC;

XIII - Livro Registro de Controle de Crédito de ICMS do Ativo Permanente - CIAP;

XIV - Livro de Movimentação de Produtos - LMP.[...]

Dando sequência o Art. 227 ao 229 dispõe:

Art. 227 Os livros fiscais, que serão impressos e de folhas numeradas tipograficamente em ordem crescente, só serão usados depois de visados pela repartição arrecadadora de domicílio fiscal do contribuinte.[...]

Art. 228 Os lançamentos nos livros fiscais serão feitos a tinta, com clareza, não podendo a escrituração atrasar-se por mais de 5 (cinco) dias, ressalvados os livros para cuja escrituração forem atribuídos os prazos especiais.[...]

Art. 229 A escrituração fiscal somente será reconstituída quando, evidenciada a impossibilidade ou a inconveniência de saneá-la por meio de lançamentos corretivos seja:

I - autorizada pelo fisco, requerimento do contribuinte; ou

II - determinada pelo fisco.[...]

Sendo assim são classificados como Livros Fiscais documentos onde armazenam fatos relacionados com as atividades fiscais da empresa. É através deles que são extraídas informações úteis que auxiliam nas tomadas de decisões.

\subsubsection{Livro Registro de Entrada}

Segundo o Art. 218 da Lei no 7.098/98:

Art. $218 \mathrm{O}$ livro Registro de Entradas, modelo 1 ou $\underline{1-\mathrm{A}}$, destina-se à escrituração do movimento de entradas de mercadorias e/ou serviços a qualquer título, no estabelecimento.

$\S 1^{\circ}$ - Serão também escriturados os documentos fiscais relativos às aquisições de mercadorias que não transitarem pelo estabelecimento adquirente.

$\S 2^{\circ}$ - Os lançamentos serão feitos por operação ou prestação, em ordem cronológica das entradas efetivas de mercadorias no estabelecimento ou, na hipótese do parágrafo anterior, de sua aquisição ou desembaraço aduaneiro, ou, ainda, da utilização dos serviços de transporte e de comunicação.

$\S 3^{\circ}$ - Os lançamentos serão feitos documento por documento, desdobrados em tantas linhas quantas forem as alíquotas do imposto e as naturezas das operações ou prestações.

Dessa forma o Livro Registro de Entradas compreende todo o movimento de entrada da empresa, sendo que todas essas entradas deverão ser lançadas uma a uma de forma cronológica.

\subsubsection{Livro Registro de Saída}

De acordo com o Art. 219 da Lei no 7.098/98:

Art. 219 O Livro Registro de Saídas, modelo 2 ou 2-A, destina-se à escrituração do movimento de saídas de mercadorias, a qualquer título, e de prestação de serviços de 
transporte e de comunicação.

$\S 1^{\circ}$ - Serão também escriturados os documentos fiscais relativos às transmissões de propriedades das mercadorias que não tenham transitado pelo estabelecimento. $\S 2^{\circ}$ - Os lançamentos serão feitos em ordem cronológica, segundo as datas de emissão dos documentos fiscais, pelos totais diários, com desdobramento em tantas linhas quantas forem as alíquotas aplicadas às operações ou prestações de mesma natureza, de acordo com o Código Fiscal de Operações e Prestações, sendo permitido o registro conjunto dos documentos de numeração seguida da mesma série e subsérie.

Assim o Livro Registro de Saída abrange todos os movimentos de saída de mercadoria da empresa, devendo ser lançadas de forma cronológica e de acordo com o Código Fiscal de Operações e Prestações.

\subsection{Escrituração Fiscal Digital - EFD}

Com o aumento da tecnologia e a importância da escrituração fiscal se tornou indispensável que a informação chegue aos usuários de forma rápida e confiável. O Estado que é um importante usuário, pelo fato de diminuir a sonegação fiscal, instituiu a instalação da Escrituração Fiscal Digital (EFD) através do Convenio ICMS nº 143 de 15 de dezembro de 2006.

De acordo com a Receita Federal sítio do SPED:

A Escrituração Fiscal Digital - EFD é um arquivo digital, que se constitui de um conjunto de escriturações de documentos fiscais e de outras informações de interesse dos fiscos das unidades federadas e da Secretaria da Receita Federal do Brasil, bem como de registros de apuração de impostos referentes às operações e prestações praticadas pelo contribuinte. Este arquivo deverá ser assinado digitalmente e transmitido, via Internet, ao ambiente Sped.

A Escrituração Fiscal Digital compreende os livros: Registro de Entrada, Registro de Saída, Registro de Inventário, Registro de Apuração de ICMS e Documento Controle de Crédito de ICMS do Ativo Permanente - CIAP. Através dela a empresa fica isenta da obrigação de impressão de Livros Fiscais.

Nela conterá informações que de alguma forma venham a influenciar na apuração, pagamento ou cobrança dos impostos, havendo omissão ou imprecisão dessas informações, o contribuinte poderá receber uma notificação eletrônica vinda da Secretaria de Estado de Fazenda de Mato Grosso (SEFAZ/MT).

Fica por conta do ambiente nacional do Sistema Público de Escrituração Digital (SPED) administrado pela Secretaria da Receita Federal do Brasil a recepção e validação das informações referentes à EFD. Em caso de empresas com filial, sucursal, agência ou outro qualquer, necessitará apresentar um arquivo digital para cada uma individualmente.

A EFD deverá ser assinada digitalmente e transmitida até o ultimo dia útil da primeira 
quinzena do mês subsequente ao período informado. Os arquivos digitais da EFD juntamente com os documentos que deram origem a escrituração deverão ser mantidos pelo contribuinte pelo prazo decadencial do crédito tributário.

\subsection{Sistema Público de Escrituração Digital - SPED}

De acordo com o Decreto $n^{\circ} 6.022$ de 22 de Janeiro de 2007 o objetivo do SPED é "unificar as atividades de recepção, validação, armazenamento e autenticação de livros e documentos que integram a escrituração comercial e fiscal dos empresários e das sociedades empresárias, mediante fluxo único, computadorizado, de informações".

Segundo Receita Federal, sítio do SPED:

A partir de sua base de dados, a empresa deverá gerar um arquivo digital de acordo
com leiaute estabelecido em Ato COTEPE, informando todos os documentos fiscais
e outras informações de interesse dos fiscos federal e estadual, referentes ao período
de apuração dos impostos ICMS e IPI. Este arquivo deverá ser submetido à
importação e validação pelo Programa Validador e Assinador (PVA) fornecido pelo
Sped.

Apesar do Estado ser o principal interessado no SPED, ele não será o único a ser beneficiado, as empresas e a sociedade também serão.

Para o Estado haverá melhor qualidade nas informações, melhor controle fiscal, redução da sonegação, maior integração entre o fisco federal, estadual e municipal, redução e eliminação de fraudes, já para as empresas acarretará em melhor ambiente de negócios com racionalização e aumento de competitividade por conta da diminuição da concorrência desleal, simplificação das obrigações fiscais, redução de custos de impressão, melhoria e aperfeiçoamento dos processos internos, incentivo ao comercio eletrônico entre empresas e preservação do meio ambiente com a redução do consumo do papel.

\section{METODOLOGIA}

Nas palavras de Filho e Santos (2000, P.64) a metodologia "é a forma de como utilizar os recursos disponíveis, a apresentação dos objetivos e o procedimento do pesquisador para atingir o resultado esperado."

GIL (2002, P. 42) ensina que "o objetivo fundamental da pesquisa é descobrir respostas para problemas mediante o emprego de procedimentos científicos".

A metodologia a ser utilizada neste trabalho segundo a abordagem dos objetivos foi o método descritivo e explicativo.

Descritivo, pois se descreve sobre a importância das informações da Escrituração 
Fiscal para a tomada de decisões das farmácias de Tangara da Serra-MT e explicativo por aprofundar mais o conhecimento sobre a importância da Escrituração Fiscal.

Quanto à abordagem dos procedimentos será utilizada a pesquisa bibliográfica e levantamento de dados. Bibliográfica por utilizar livros e artigos científicos e levantamento de dados onde foi utilizado conjunto de dados para a elaboração deste artigo.

Conforme GIL (2002, P. 65):

"A pesquisa bibliográfica é desenvolvida a partir de material já elaborado, constituído principalmente de livros e artigos científicos. [...]".

De acordo com GIL (2002, P. 58) o levantamento de dados:

“[...] Basicamente, procede-se à solicitação de informações a um grupo significativo de pessoas acerca do problema estudado para, em seguida, mediante análise quantitativa, obter as conclusões correspondentes aos dados coletados."

Desta forma, foram aplicados dois questionários, o primeiro foi aplicado nos escritórios de contabilidade que totalizam 25 e outro nas empresas do ramo farmacêutico que totalizam 35, situados em Tangará da Serra- MT. Este questionário foi composto por perguntas fechadas e foi aplicado entre o dia 15 de julho de 2011 e 30 de julho de 2011,com a finalidade de obter dados mais aprofundados a respeito do tema abordado.

E na abordagem do problema, que constitui o objeto de estudo, a aplicabilidade dessa pesquisa foi quantitativa e qualitativa.

Segundo Vergara (2004, P. 59) os dados podem ser tratados de forma "Quantitativo utilizando-se procedimentos estatísticos e Qualitativo codificando-os, apresentado-os de forma mais estruturada e analisando-os."

\section{RESULTADOS E DISCUSSÃO}

Os resultados desta pesquisa foram apresentados na forma de gráfico e relatórios, de acordo com as respostas dos questionários que foram aplicados em 25 escritórios de contabilidade e em 35 farmácias.

A contabilidade influência a tomada de decisões das empresas à medida que o gestor se utiliza das informações por esta ciência gerada. Segundo Fayol (1994) a Contabilidade, constitui-se no órgão de visão das empresas, revelando a posição e o rumo do negócio, em qualquer momento, dando informações exatas, claras e precisas sobre a situação econômica 
da empresa.

\subsection{Resultados}

Os escritórios de contabilidade de Tangará da Serra são representados em sua maioria por homens $(80 \%)$ conforme Figura 1 (A). Das pessoas pesquizadas $60 \%$ delas são gerentes e os outros $40 \%$ são proprietários conforme Figura 1 (B). Destes representantes 32\% possuem idade entre 36 e 41 anos conforme Figura 1 (C), demonstrando assim através da Figura 1 (D), que $76 \%$ dos entrevistados possuem nível superior, pois o desenvolvimento das empresas caminha junto com o desenvolvimento do conhecimento de seus respectivos escritórios de contabilidade e com grau de escolaridade maior, possuem visão ampliada, podendo assim auxiliar melhor os seus clientes nas tomadas de decisão. Fazendo com que os próprios escritórios de contabilidade procurem se capacitar a cada mudança que vêem a ocorrer em nossa legislação e em nosso cotidiano. 
FIGURA 1: Identificação dos pesquisados: Sexo (A), Cargo (B), Idade (C) e Escolaridade (D).

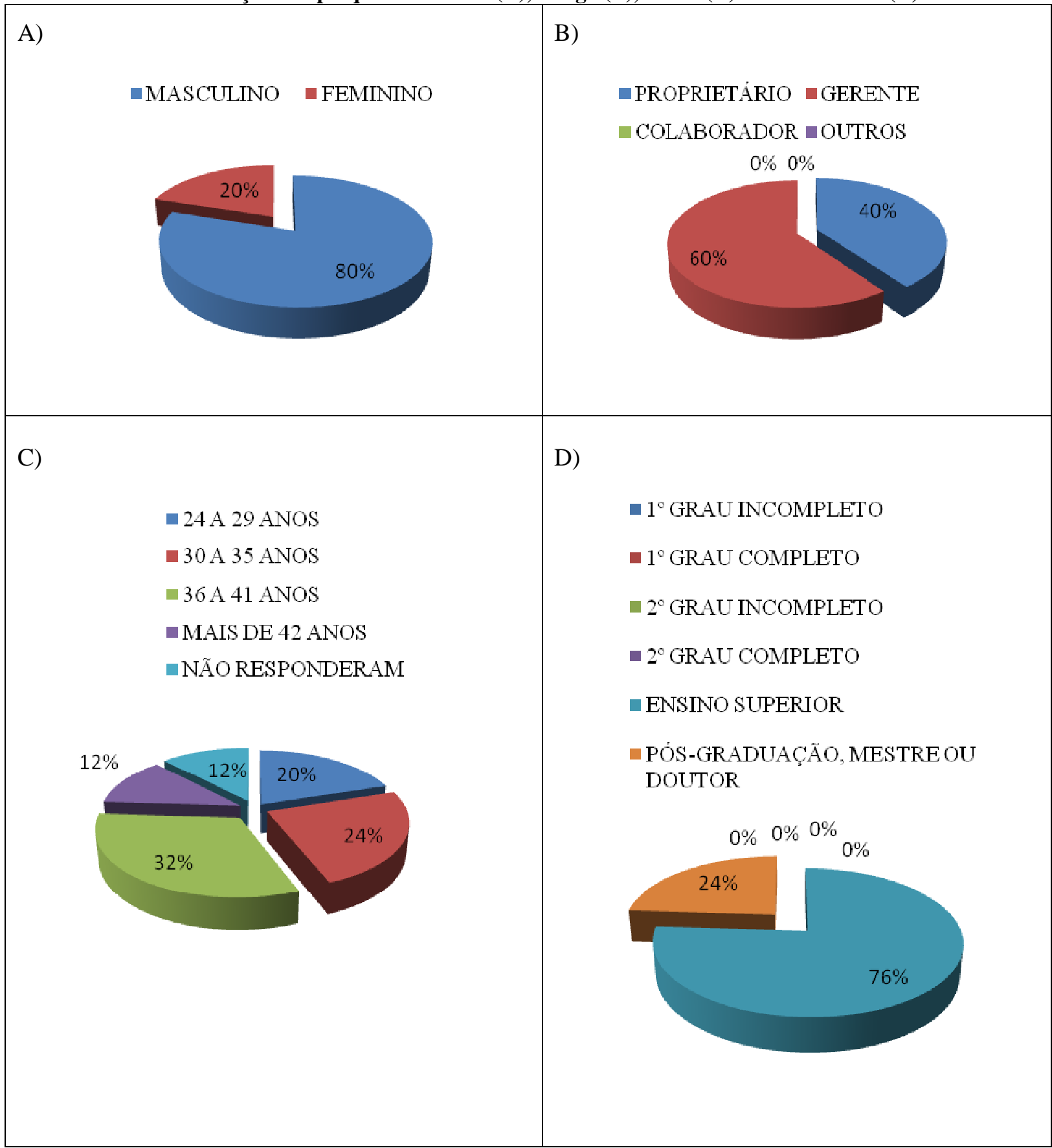

Fonte: Dados da Pesquisa

Foi possível identificar na Figura 2 (A) que 56\% dos escritórios de contabilidade são micro empresa e, os outros $44 \%$ são empresa de pequeno porte. Com relação ao tempo que atua em Tangará da Serra, $60 \%$ dos escritórios de contabilidade estão no mercado a mais de 10 anos, conforme Figura 2 (B). Já as pessoas pesquizadas $80 \%$ delas estão na empresa a mais 
de 5 anos, conforme mostra a Figura 2 (C). Identifica-se também que 52\% dos escritórios de contabilidade possuem de 10 a 20 funcionários, conforme Figura 2 (D).

FIGURA 2: Identificação da empresa entrevistada: Porte da empresa (A), Tempo que a empresa atua em Tangará (B), Tempo que atua na empresa (C) e Quantidade de funcionários (D).

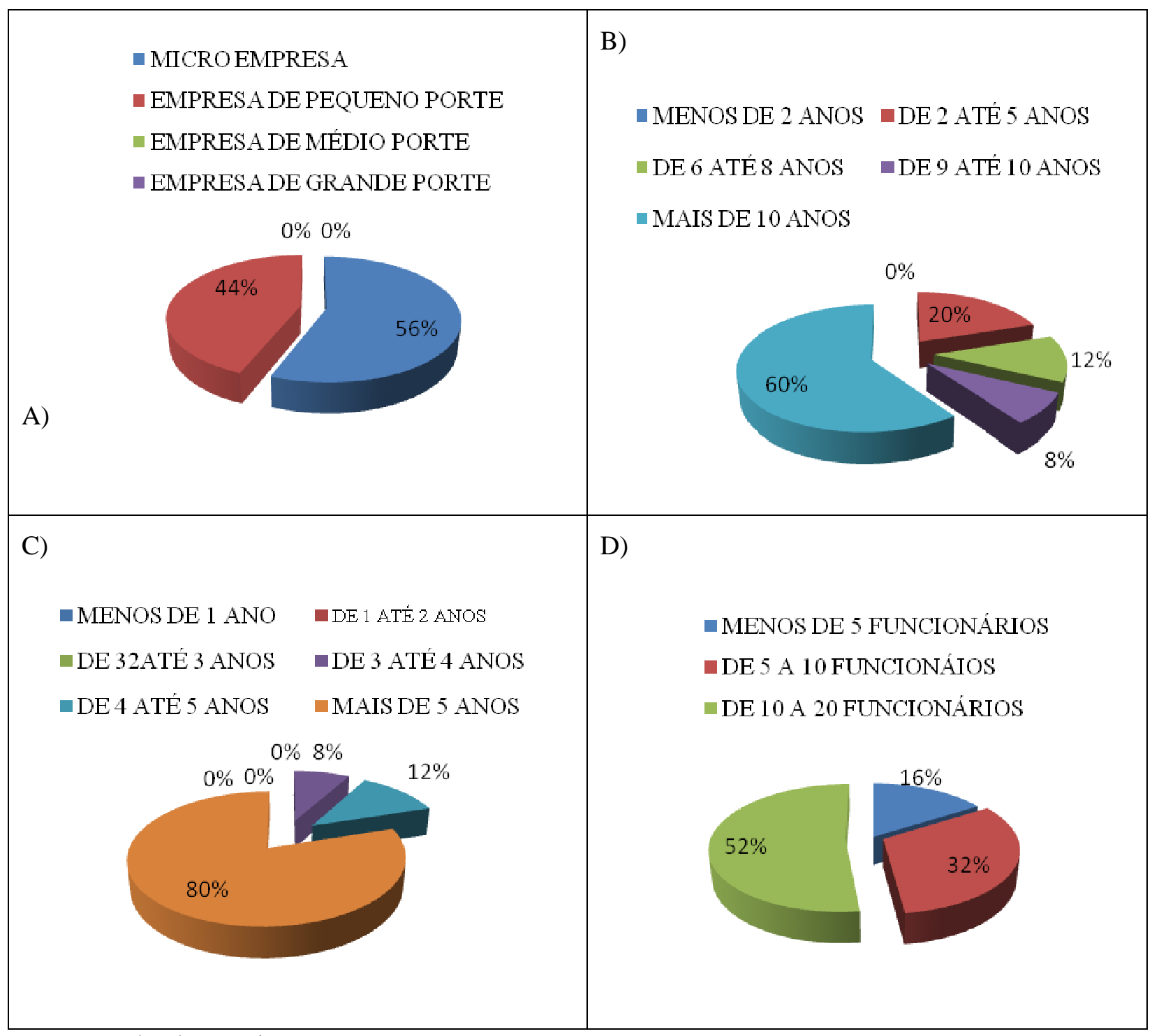

Fonte: Dados da Pesquisa

Quando questionados, 100\% dos escritórios de contabilidade, de acordo com a Figura 3 (A), afirmaram que a empresa conhece o conceito de escrituração fiscal e que $100 \%$ deles oferecem aos seus funcionários treinamento para a elaboração da escrituração fiscal conforme Figura 3 (B).

Quanto a importância da escrituração fiscal, 100\% dos pesquizados responderam que é importante para governo, fornecedores, políticos, clientes e ferramentas de gestão, ou seja 
todas as alternativas conforme Figura 3 (C). Disseram, 100\% deles também, que é importante que as empresas do ramo farmacêutico possuam conhecimento a respeito da escrituração fiscal, conforme Figura 3 (D).

FIGURA 3: Conceito de Escrituração Fiscal (A), A empresa oferece treinamento para a elaboração da Escrituração Fiscal (B), Escrituração Fiscal importante para: (C) É necessário possuir conhecimento sobre a Escrituração Fiscal (D).

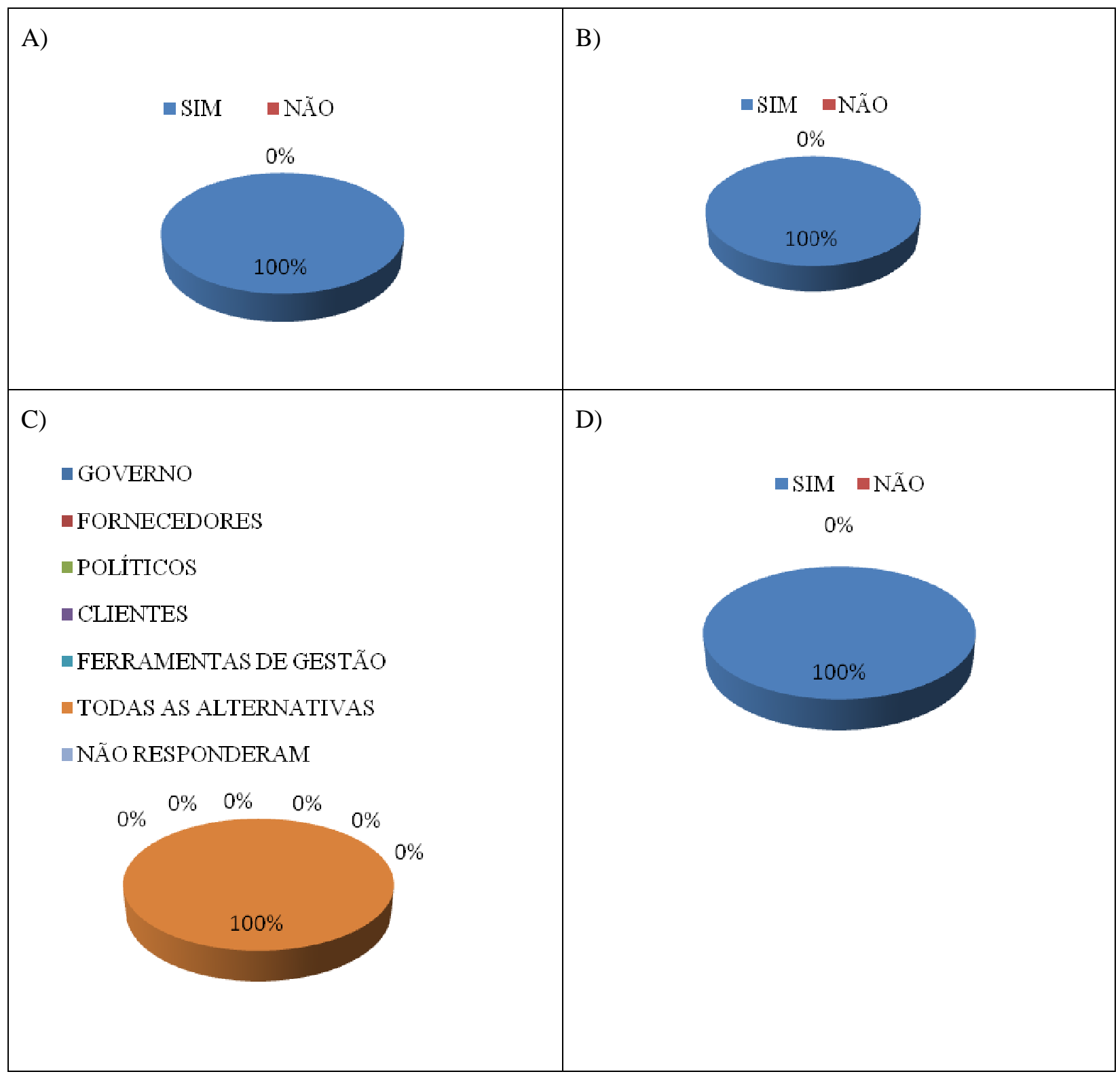

Fonte: Dados da Pesquisa

Dos escritórios de contabilidade, $100 \%$ afirmam que oferecem informação a respeito da importância da escrituração fiscal, conforme Figura 4 (A). Sobre a implantação da escrituração fiscal nas empresas do ramo farmacêutico, $32 \%$ dizem que a maior dificuldade é 
a falta de conhecimento técnico, como mostra a Figura 4 (B), porém $84 \%$ dizem que as empresas do ramo farmacêutico não se interessam em saber o conceito da escrituração fiscal, conforme Figura 4 (C). Conforme Figura 4 (D), 56\% das empresas utilizam a escrituração fiscal como influência para a tomada de decisão.

FIGURA 4: O escritório de contabilidade oferece informação a respeito da importância da Escrituração Fiscal (A), A maior dificuldade para a implantação da Escrituração Fiscal nas farmácias (B), Os clientes das farmácias se interessam em saber o conceito e a importância da Escrituração Fiscal (C) e A Escrituração Fiscal influência na tomada de decisão das farmácias(D).

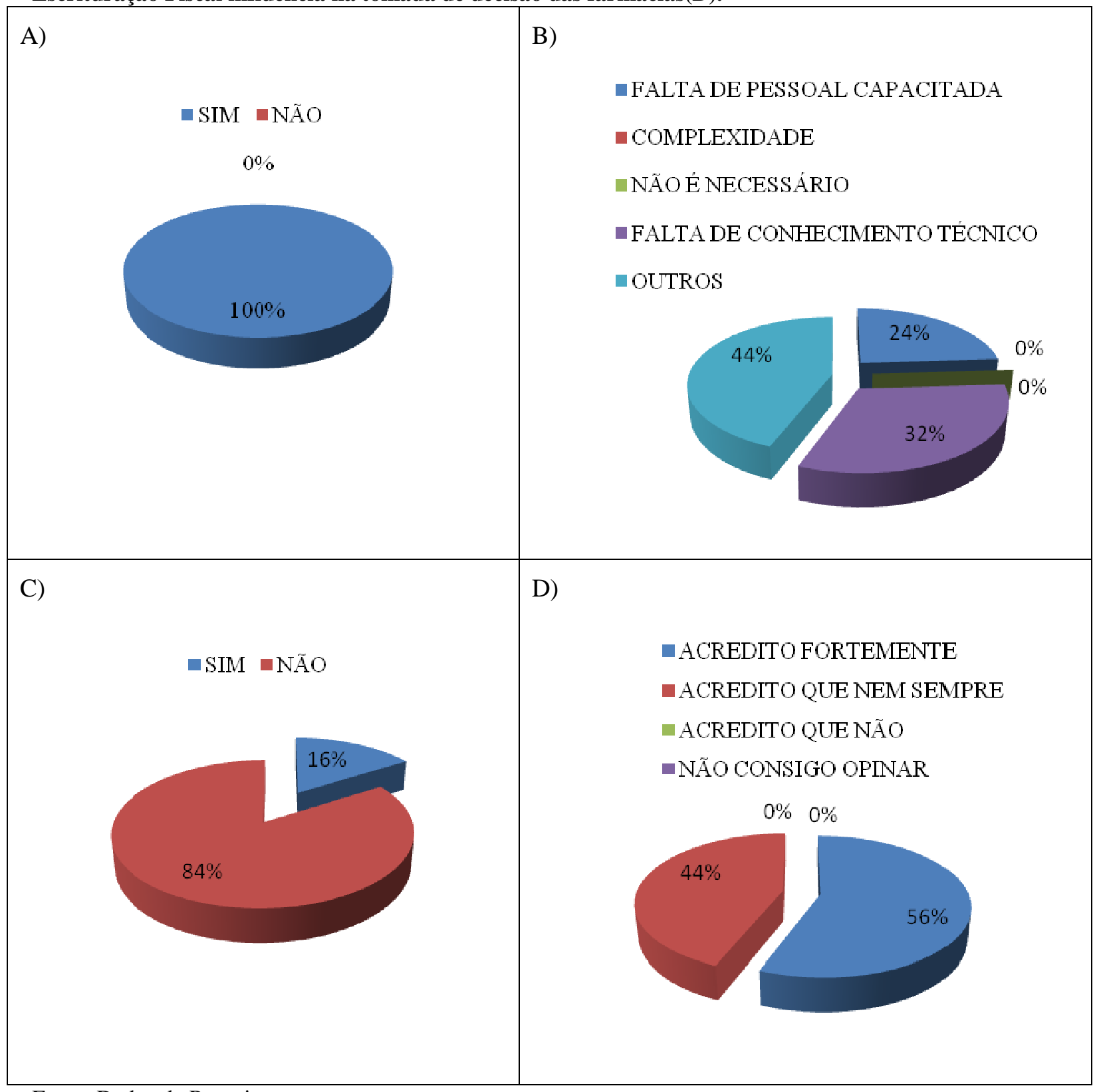

Fonte: Dados da Pesquisa

Através da análise dos questionários aplicados, pode-se observar também que 100\% 
das informações transmitidas pelos escritórios de contabilidade correspondem a impostos, estoque e movimentação fiscal, conforme Figura 5 (A). A respeito dos impostos, $100 \%$ dos entrevistados afirmam que as informações transmitidas são sobre a alíquota, a influência no faturamento e o montante pago em relação ao movimento fiscal, conforme Figura 5 (B). Já os estoques, conforme Figura 5 (C), de acordo com os pesquizados, podem transmitir informações sobre quantidade de mercadoria, o valor dos impostos nele aplicados e o giro do estoque na empresa.

FIGURA 5: Identificação das informações: Quais são? (A), a respeito de impostos (B), a respeito de estoque C).

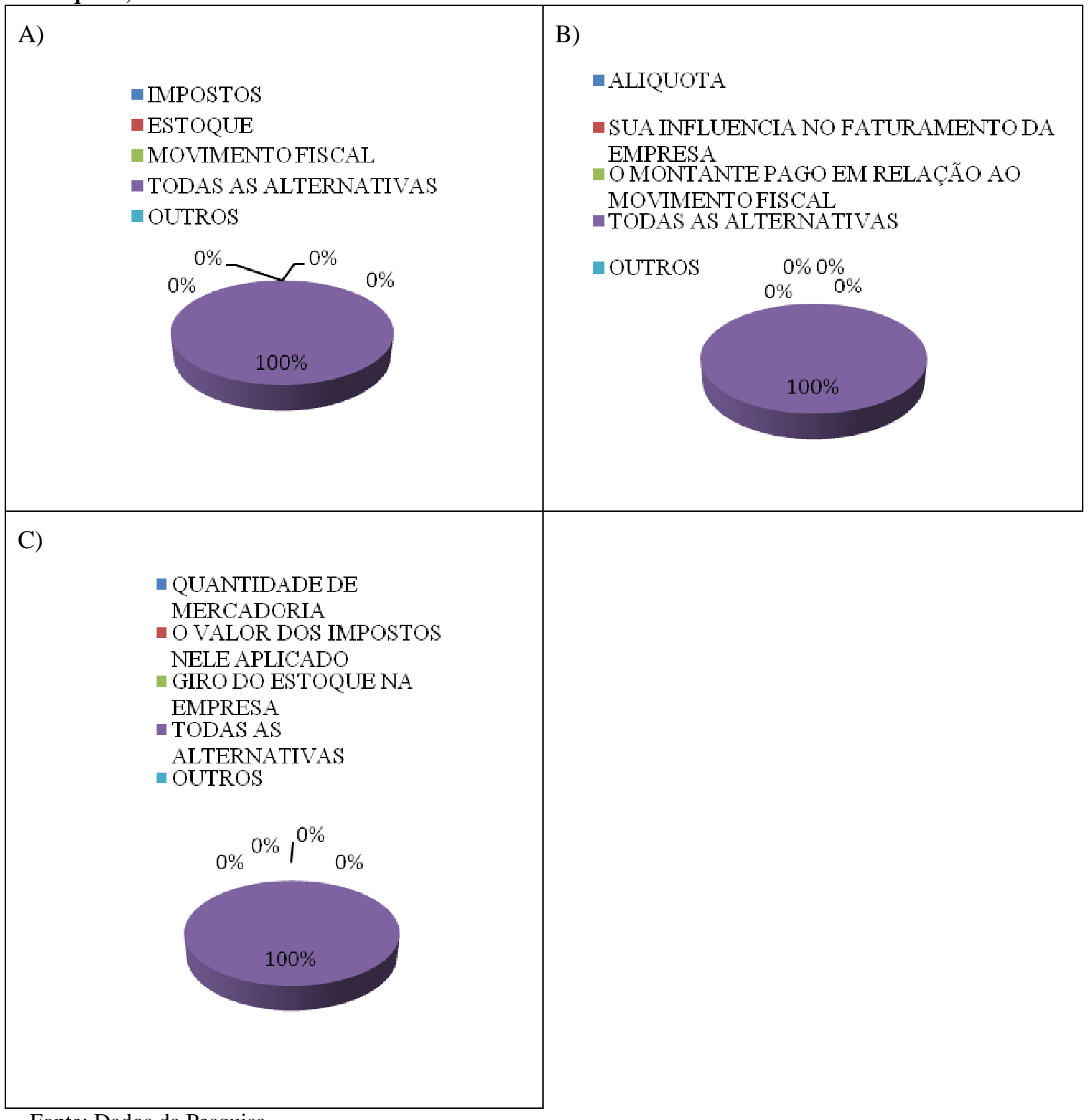

Fonte: Dados da Pesquisa 
Conforme Figura 6 (A) os entrevistados afirmaram que a informação retirada da Escrituração Fiscal é útil e conforme a Figura 6 (B) 50\% dos questionados atestam que a informação pode ser utilizada na tomada de decisão e 50\% no controle das entradas e saídas. Quando questionados com que frequiência os escritórios informam onde os clientes poderão aplicar essas informações $80 \%$ dos escritórios responderam que sempre conforme Figura 6 (C).

FIGURA 6: Identificação das informações: É útil? (A), pra qual finalidade (B) com qual freqüência são informados de onde utilizá-las (C).

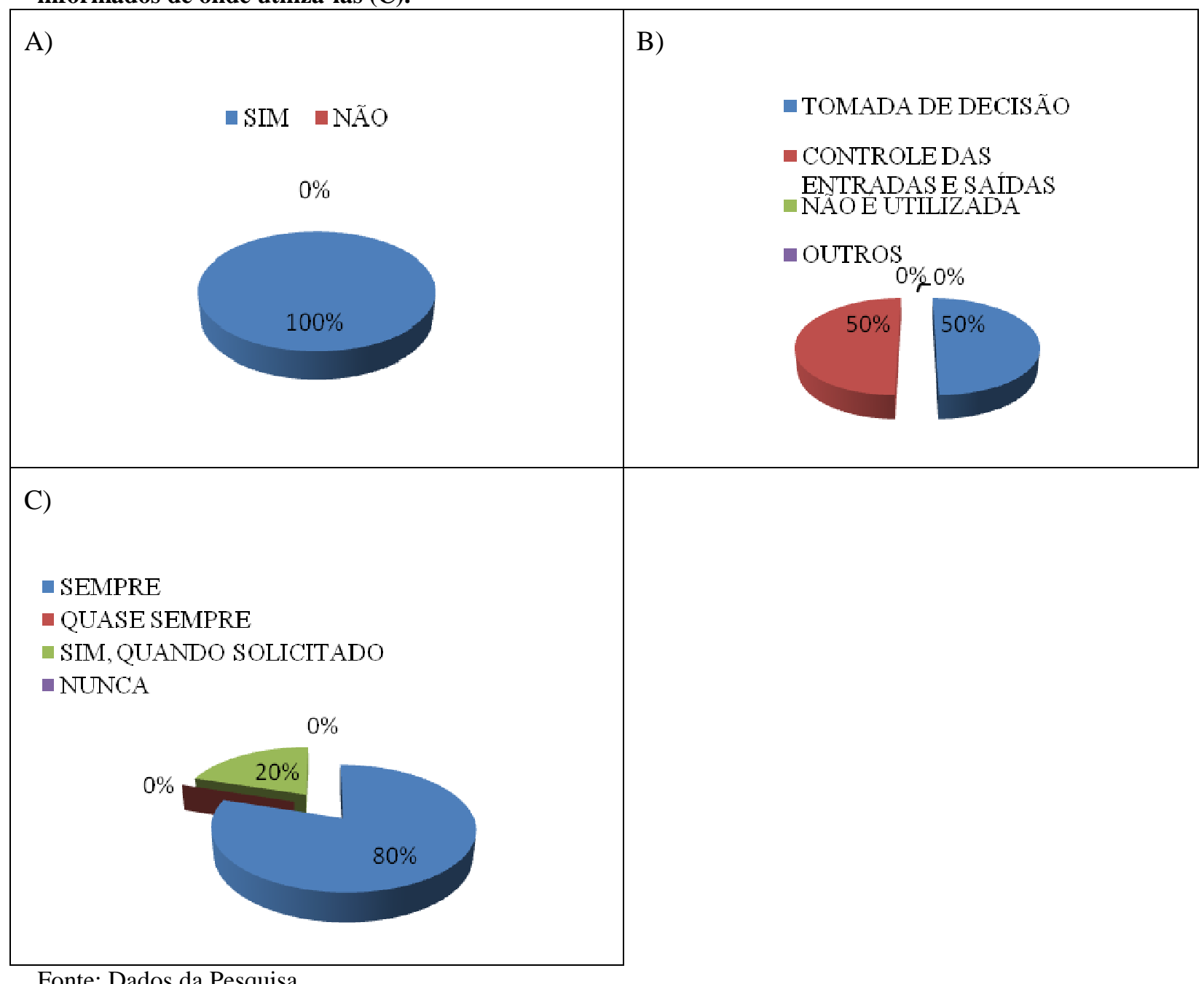

Fonte: Dados da Pesquisa

No questionário aplicado nas farmácias pode-se observar que 54\% das pessoas que os responderam são proprietários, conforme Figura 7 (A) e que em sua maioria, 74\%, são do sexo masculino, conforme Figura 7 (B) e, possuem idade maior que 42 anos, conforme Figura 
7 (C). Já o grau de escolaridade, em $40 \%$ delas é de $2^{\circ}$ grau Completo, conforme Figura 7 (D). FIGURA 7: Identificação dos pesquisados: Sexo (A), Cargo (B), Idade (C) e Escolaridade (D).

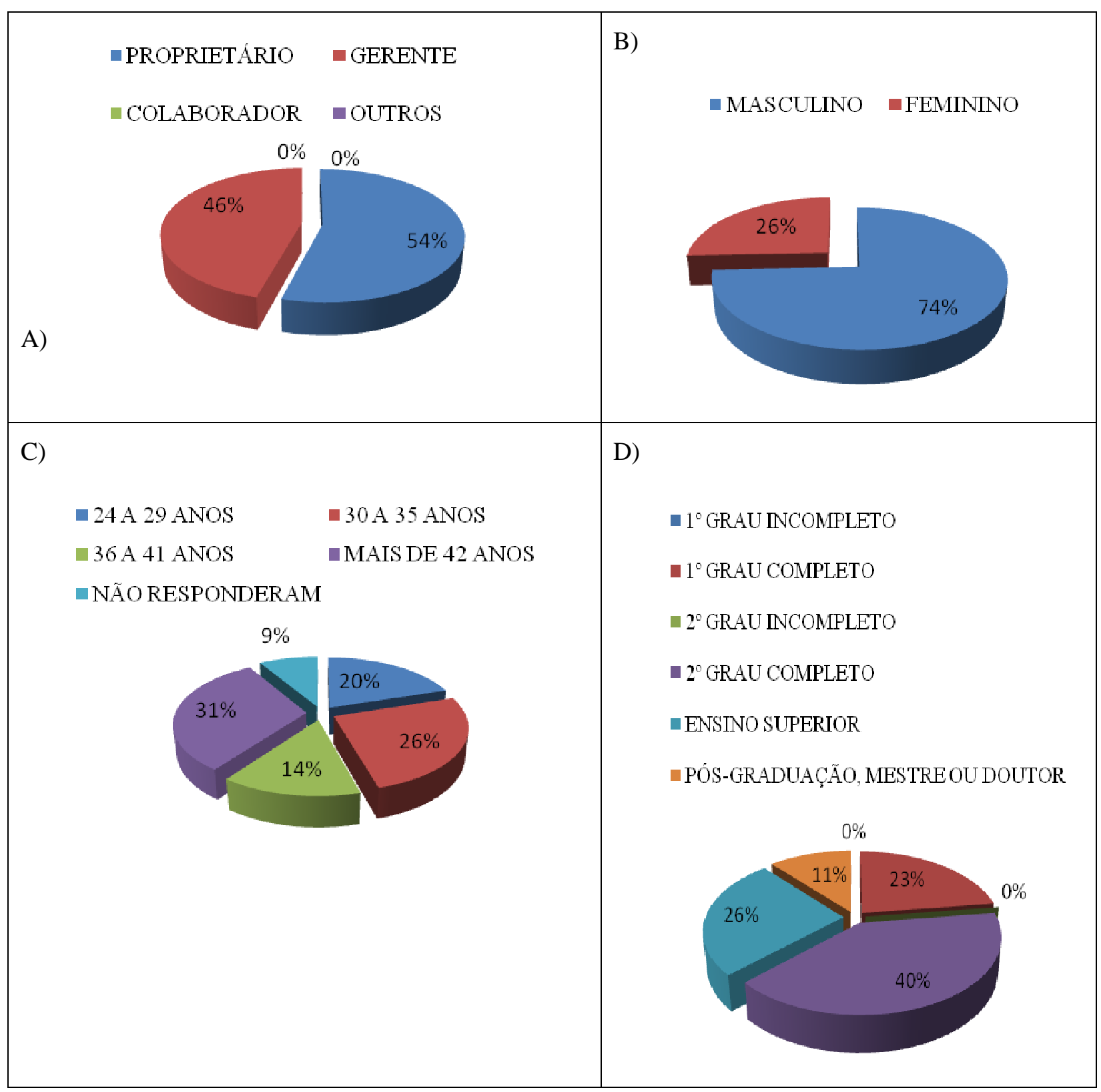

Fonte: Dados da Pesquisa

Das empresas questionadas $46 \%$ se encontram em Tangará da Serra- MT a mais de 10 anos, de acordo com o gráfico da Figura 8 (A), e pesquisado, conforme Figura 8 (B), está na empresa a mais de 5 anos. As empresas em sua maioria, 94\%, são micro empresas, conforme Figura 8 (C), e 77\% possuem menos de 5 funcionários, conforme Figura 8 (D). 
FIGURA 8: Identificação da empresa: Tempo que a empresa atua em Tangará (A), Tempo que atua na empresa (B), Por porte da empresa (C) e Quantidade de funcionários (D).

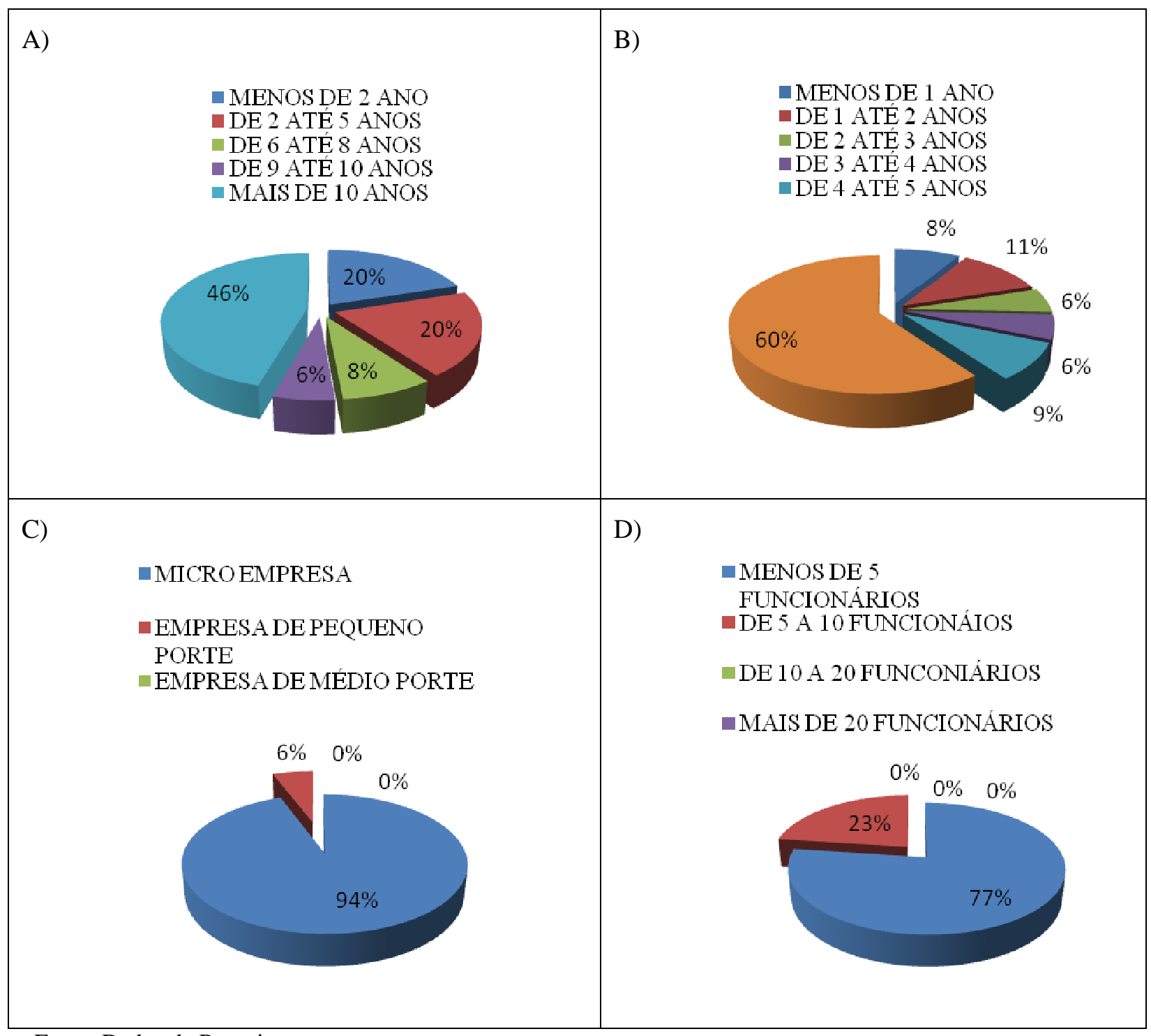

Fonte: Dados da Pesquisa

Questionadas, 63\% das empresas do ramo farmacêutico garantem que conhecem o conceito de escrituração fiscal, conforme Figura 9 (A) e acham que a escrituração fiscal é em sua maior parte, 43\%, importante para o governo, conforme Figura 9 (B). Porém 89\% afirmam que é necessário que seus funcionários do setor administrativo possuam conhecimento sobre a escrituração fiscal, conforme figura 9 (C). Quando foi perguntado se os escritórios de contabilidade oferecem informação a respeito da importância da escrituração fiscal, $80 \%$ responderam que sim, Figura 9 (D). 
FIGURA 9: Conhece o conceito de Escrituração Fiscal (A), Escrituração Fiscal importante para: (B), Necessidade dos funcionários administrativos das farmácias conhecer a Escrituração Fiscal (C) e Os escritórios de contabilidade oferece informação a respeito da importância da Escrituração Fiscal (D).

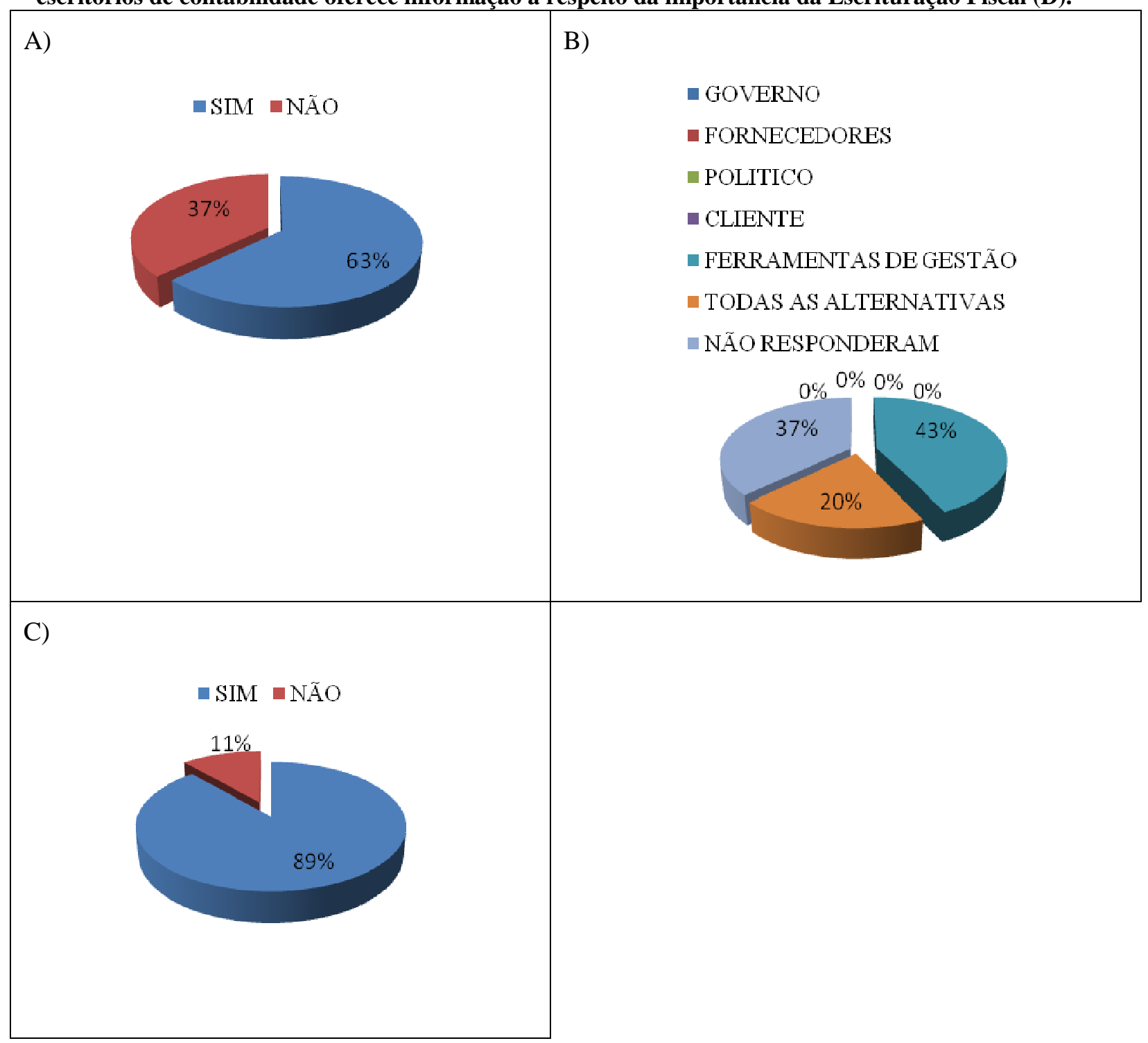

Fonte: Dados da Pesquisa

Contudo, $43 \%$ das farmácias dizem que a falta de pessoal capacitado dificulta a implantação da escrituração fiscal na própria empresa, conforme Figura 10 (A). Afirmaram ainda que a falta de conhecimento a respeito da importância da escrituração fiscal dificulta a tomada de decisão da empresa, conforme Figura 10 (B), porém 54\% utilizam a escrituração fiscal como referência para a tomada de decisão, conforme Figura 10 (C) 
FIGURA 10: A maior dificuldade para a implantação da escrituração fiscal na empresa (A), A falta de conhecimento a respeito da escrituração fiscal dificulta a tomada de decisão da empresa (B) e A empresa utiliza a escrituração fiscal como referência para a tomada de decisão (C).

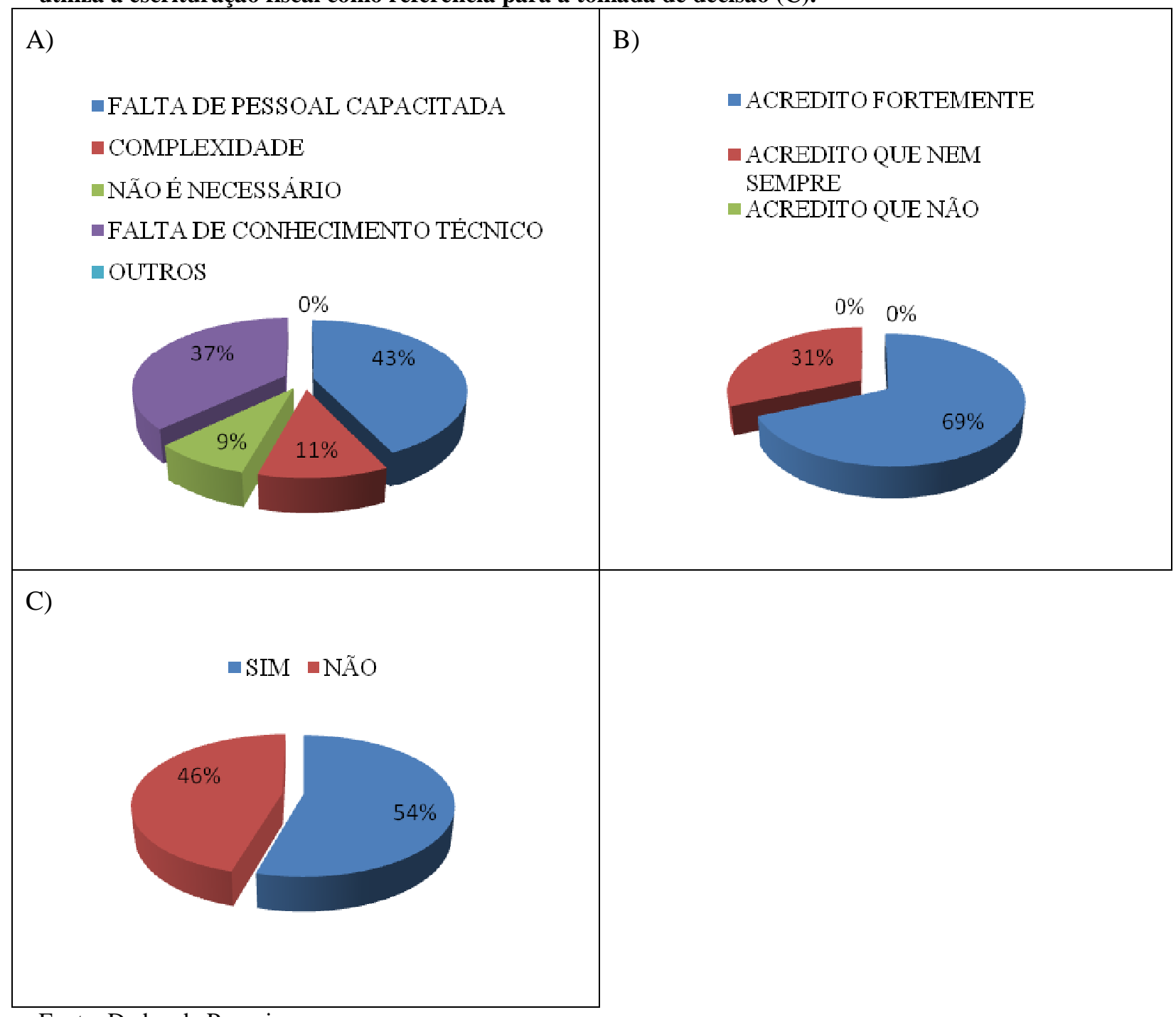

Fonte: Dados da Pesquisa

Quando questionadas sobre quais são as informações, a respeito da Escrituração Fiscal, que o escritório de contabilidade transmite as farmácias, 100\% delas atestaram que os impostos, o estoque e o montante fiscal, conforme Figura 11 (A). Contudo, a respeito dos impostos, 66\% das farmácias recebem informações sobre a alíquota, sua influencia no faturamento e o montante pago em relação ao movimento fiscal, conforme Figura 11 (B). A respeito do estoque, $69 \%$ afirmam que recebem informações sobre quantidade de mercadoria, valor dos impostos nele aplicados e o giro do estoque da empresa, conforme Figura 11 (B). 
FIGURA 11: Identificação das informações: Quais são? (A), a respeito de impostos (B), a respeito de estoque C) e pra qual finalidade (D).

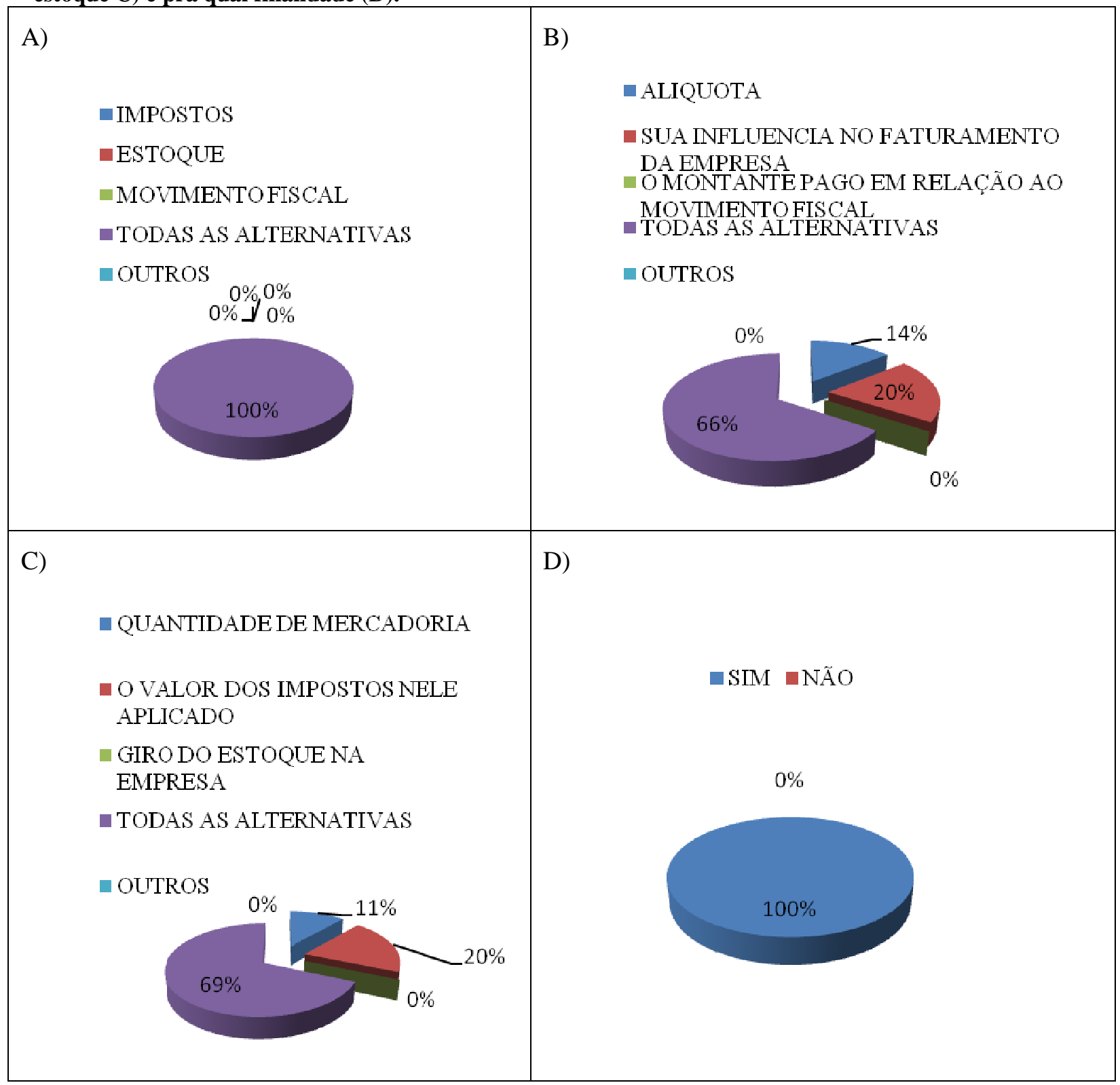

Fonte: Dados da Pesquisa

Sobre a utilidade das informações, 80\% confirmam a sua importância, conforme Figura 12 (A). E quanto a sua finalidade, de acordo com a Figura 12 (B), $49 \%$ é direcionada para a tomada de decisão. Quando questionados se os escritórios os informam onde poderão aplicar as informações, $77 \%$ das farmácias responderam que somente quando solicitado. 
FIGURA 12 : Identificação das informações: É útil? (A), pra qual finalidade (B) com qual freqüência são informados de onde utilizá-las (C).

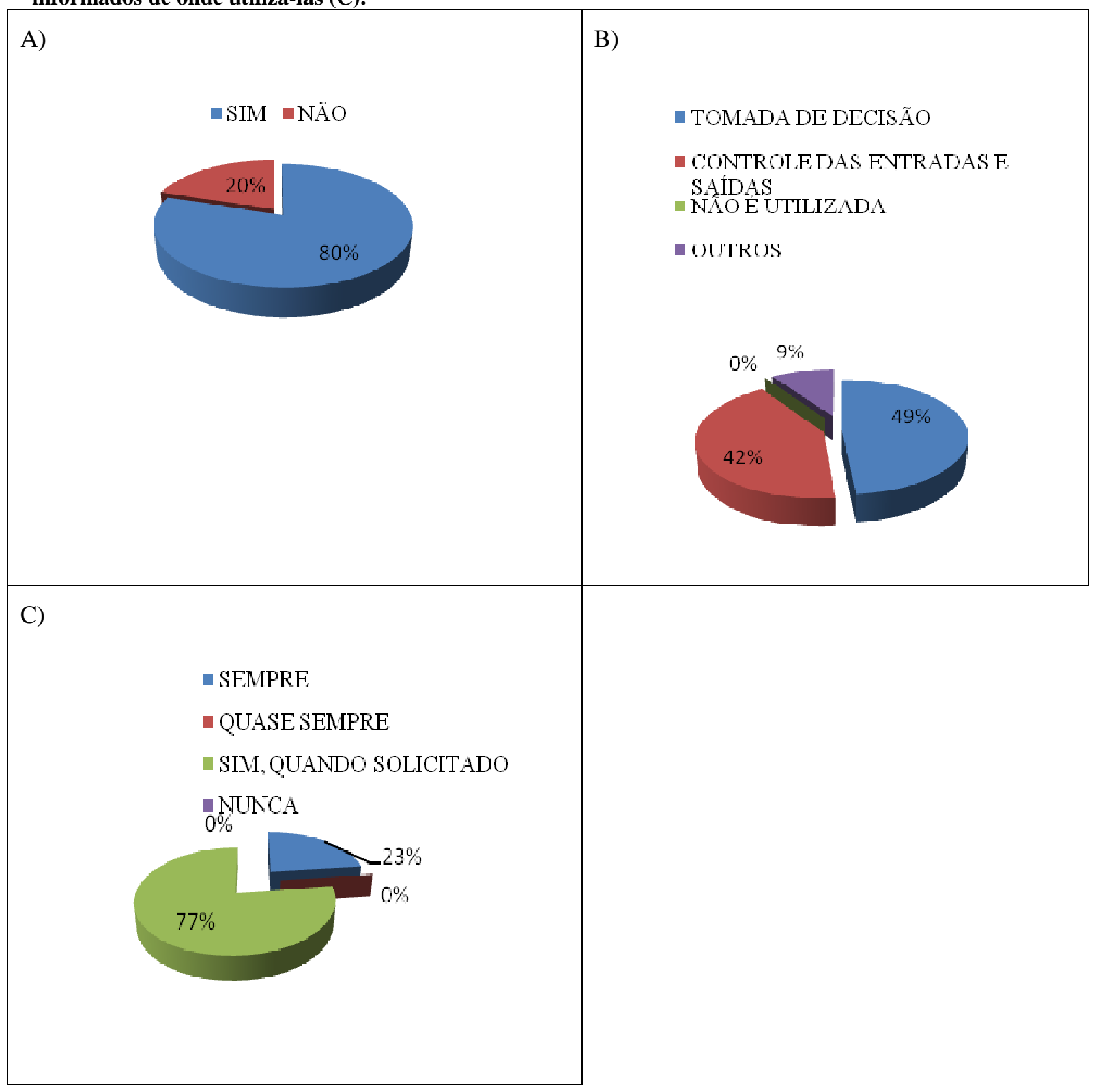

Fonte: Dados da Pesquisa

As informações transmitidas pelos escritórios de contabilidade deverão chegar aos usuários transformados em relatórios geradores de conhecimento, onde eles possibilitem a compreensão e auxiliem nas tomadas de decisões.

\subsection{Discussão}

Através dos resultados obtidos, pode-se observar que 100\% dos escritórios de contabilidade afirmam que transmitem informações a respeito da importância da escrituração 
fiscal para seus clientes do ramo farmacêutico, porém apenas $80 \%$ dos clientes afirmaram que recebem esta informação. E quando foram questionados quando a aplicabilidade desta informação, apenas 54\% delas garantiu que as utilizam para a tomada de decisão.

Quando questionados sobre qual a informação que os escritórios de contabilidade transmitem aos seus clientes do ramo comercial farmacêutico, as respostas pesquisadas se concretizam, pois $100 \%$ dos escritórios afirmam que transmitem informações a respeito de impostos, estoque e movimento fiscal, atestado pelas farmácias que também afirmam 100\% essa informação.

Já as informações a respeito dos impostos, enquanto 100\%dos escritórios afirmam que transmitem informações sobre alíquota, sua influencia no faturamento e o montante pago em cima dos movimentos da empresa, apenas $66 \%$ das farmácias questionadas afirmam que as recebem. Em relação ao estoque, 100\% dos escritórios também afirmam que transmitem informações sobre quantidade de mercadoria, o valor dos impostos nele aplicados e o giro do estoque na empresa, porem, apenas $69 \%$ das farmácias atestam que recebem.

Sobre a utilidade da informação retirada da escrituração fiscal, 100\% dos escritórios de contabilidade disseram que é utilizada na tomada de decisão e controle das entradas e saídas, porem somente $83 \%$ das farmácias confirmam essa finalidade.

Foi questionado também se o escritório de contabilidade explica onde as informações, a respeito da escrituração fiscal, podem ser utilizadas, no qual $80 \%$ disseram que sempre informam, mas 77\% das empresas do ramo farmacêutico afirmam que só são quando a mesma solicita.

\section{CONSIDERAÇÕES FINAIS}

O estudo apresentado neste artigo teve por objetivo identificar a importância da Escrituração Fiscal na visão dos empresários do ramo farmacêutico de Tangará da Serra - MT e também analisar se os escritórios de Tangará da Serra - MT informam aos seus clientes quanto à importância da escrituração fiscal no segmento comercial farmacêutico; demonstrando que as informações geradas pelo profissional contábil são necessárias para auxiliar no processo decisório de suas empresas, garantindo assim o sucesso destas.

O interesse da pesquisa incidiu sobre a importância da Escrituração Fiscal para a tomada de decisão das empresas do ramo farmacêutico de Tangará da Serra - MT, visto que as informações contábeis têm a finalidade de transmitir dados que venham a facilitar as tomadas de decisões. 
As empresas do ramo farmacêutico são administradas em sua maioria por seus proprietários. A maioria dos entrevistados das empresas pesquisadas, afirmaram que os registros fiscais são realizados no escritório contábil e estão no mercado Tangaraense a mais de cinco anos. Das atribuições assumidas pelos contadores nas organizações, destacam-se a de evidenciar o resultado da pesquisa em informações úteis á gestão, de forma a auxiliar os administradores no dia-a-dia. No entanto algumas empresas ainda afirmam que não recebem informações a respeito da importância da escrituração fiscal, o que leva a concluir que apesar de todos os escritórios de contabilidade afirmar que oferecem essas informações, algumas empresas ainda não sabem qual a importância e não as utilizam na tomada de decisão.

A primeira hipótese foi confirmada através da Figura 4 (A), no qual $100 \%$ dos escritórios de contabilidade questionados afirmam que informam seus clientes quanto à importância da escrituração fiscal e pode ser consolidado pela figura 5 (A), no qual 100\% deles atestam demonstrar informações a respeito de impostos, e movimento fiscal. Porém há uma divergência das informações quando analisa - se a Figura 9 (D), no qual 80\% das empresas do ramo farmacêutico afirmam que recebem informações quanto à importância da escrituração fiscal, confirmada pela figura 11(A), em que 100\% dos que recebem informação responderam e disseram que as informações transmitidas são sobre impostos, estoque e movimento fiscal.

Os profissionais da contabilidade devem estar atentos as evoluções do dia-a-dia, pois as empresas não necessitam somente de profissional com conhecimento contábeis básicos, mas de profissional que tenha domínio prático sobre as demais áreas especificas da Contabilidade, conseguindo assim criar sistema de informação contábil eficiente, para gerar informações que oriente os gestores nas suas decisões operacionais e de investimentos que objetivem a maximização do lucro da empresa.

Com base na pesquisa apresentada acima sugere -se aos empresários que não utilizam as informações passadas através da escrituração fiscal buscar mais essa alternativa que a contabilidade dispõe para auxiliar as organizações no processo de gestão, a fim de propiciar informações relevantes a respeito do seu desempenho e facilitar o seu processo de planejamento e controle. Pois a sobrevivência e o sucesso das empresas estão intimamente relacionados à sua capacidade de utilizar técnicas capazes de orientar os gestores nas decisões que precisam ser tomadas.

A Escrituração Fiscal vem se modernizando dia-a-dia e com essas mudanças, às vezes, ela acaba se tornando complexa e de difícil entendimento. Portanto fica a sugestão para que 
sejam realizadas novas pesquisas com relação a este tema para que através delas se possa facilitar o entendimento de empresários e outros estudantes, pois qualquer informação que ela venha proporcionar poderá enriquecer nosso conhecimento e orientar nas tomadas de decisões a respeito da parte fiscal da empresa, como a compra de mercadoria, pagamento de impostos e processos que influenciam no faturamento da empresa.

\section{REFERÊNCIAS BIBLIOGRÁFICAS}

AKEL, Michelle Heloise. Sistema Público de Escrituração Digital - SPED, Disponível em: <http://www.parana-online.com.br/ > Acesso em 04 de Abril de 2011

BRASIL, CONVÊNIO ICMS 143/06.

BRASIL, DECRETO 6022/07.

FAYOL, H. Administração industrial e geral: previsão, organização, comando, coordenação, controle. 10. ed. São Paulo: Atlas, 1994.

FORTES, J.C. Manual do Contabilista: Uma abordagem teórico - pratica da profissão contábil, São Paulo: Saraiva, 2005.

GIL, Antônio Carlos. Técnicas de pesquisa em economia e elaboração de monografias. 4 ed. São Paulo: Atlas, 2002.

IUDÍCIBUS, S. Teoria da Contabilidade. 8 ed. São Paulo: Atlas, 2007.

IUDÍCIBUS, S.; MARION, J.C. Introdução a Teoria da Contabilidade: para o nível de graduação. 3 ed. São Paulo: Atlas, 2002.

IUDÍCIBUS, S.; MARION, J.C. Introdução a Teoria da Contabilidade: para o nível de graduação. 4 ed. São Paulo: Atlas, 2007.

BRASIL, LEI 7098/98.

MAROJA, Danilo. Contador tem papel fundamental na constituição de novos negócios 2007. Disponível em: <http://www.advancecontabilidade.com.br> Acesso em 21 de abril de 2011

OLIVEIRA, Gustavo Pedro de. Contabilidade Tributaria. São Paulo: Editora Saraiva, 2005.

OLIVEIRA, Luiz Martins; Chieregato, Renato; Junior, Jose Hernandes Perez; Gomes, Marliete Bezerra. Manual de Contabilidade Tributaria. $6^{\circ}$ Ed., São Paulo: Editora Atlas, 
2007.

PARRA F., Domingos. SANTOS, J. A.. Apresentação de trabalhos científicos: monografia, TCC, tese e dissertações. $3^{\circ}$ Ed., São Paulo: Futura, 2000.

PEREIRA, Julio Cesar Rodrigues. Análise de dados qualitativos: estratégia metodológica para as ciências da saúde humanas e sociais. $3^{\circ}$ Ed., $1^{\circ}$ reimpressão, São Paulo: Editora Universitária de São Paulo, 2004.

BRASIL, PORTARIA N 166/2008.

RAMPAZZO, Lino. Metodologia Cientifica. $3^{\circ}$ Ed., São Paulo: Edições Loyola, 2005.

RAUPP, Elena Hahn. A contabilidade gerencial num contexto de mudanças: formulações estratégicas mediante inovações tecnológicas e organizacionais. Revista Brasileira de Contabilidade, n.123, v.29, p 25-35, maio/jun.2000.

RIBEIRO, O.M. Contabilidade Básica. São Paulo: Saraiva, 2005.

SILVA, Antonio Carlos Ribeiro de. Metodologia da pesquisa aplicada à contabilidade: orientações de estudos, projetos, relatórios, monografias, dissertações, teses. São Paulo: Editora Atlas, 2003.

SPED. Disponível em: http://www1.receita.fazenda.gov.br Acessado em 23 de Maio de 2011. VERGARA, Sylvia C.. Projetos e relatórios de pesquisa em administração. $5^{\circ}$ Ed., São Paulo: Editora Atlas, 2004. 